\title{
学生相互添削方式を取り入れた 展示用教材「ホブ盤」の設計・製作と有効性評価
}

Designing/Manufacturing of Educational Prototype Hobbing Machine for Exhibition by Instructing Method to Check Each Other's Work and Its Effective Evaluation

\author{
畧田 道 雄*1 \\ Michio UNEDA \\ 後 閑 - 洋*2 \\ Kazuhiro GOKAN \\ 石 川 憲 一*1 \\ Ken-ichi ISHIKAWA
}

Hob processing is an important machining method for fabricating the gear. However, many students and peoples cannot understand this machining mechanism because they don't have a chance to see the actual processing. With this background, we tried a creative and educational project entitled "Designing and manufacturing of hobbing machine". On the other hand, it might be a burden for the teaching staff to instruct the designing and manufacturing project. In this paper, we summarize and analyze the effect of practicing the above hobbing machine on the basis of the answers to a questionnaire provided by the guest of an exhibition. Moreover, we describe the effect of the instructing method to check each other's work to apply the designing and manufacturing project.

Keywords: Educational Prototype Machine, Hobbing Machine, Designing/Manufacturing Projects, Instructing Students to Check Each Other's Work キーワード : 展示用教材, ホブ盤, 設計・製作プロジェクト, 学生相互添削

\section{1. 緒言}

機械の動力を伝達する重要な機構並びにそれらの部 品に歯車があり, 一般的に, 歯車はホブ加工 ${ }^{1)}$ と称 される加工法で製造されている，ところで，歯車の認 知度は高いと考えられるが, 歯車製造方法であるホブ 加工となると, 一般人のみならず工科系高等教育機関 の学生であっても目の当りにする機会は少ないと考え られる。

一方，著者らが所属する金沢工業大学（工学部機械 工学科) では， 3 軸 2 段ヘリカル歯車減速機の設計・ 製図を課題とした「機械設計演習」と題する 3 年次必 修科目を開講する ${ }^{2)} と と も に ，$ 専用テキストを出版 している ${ }^{3)}$. 図 1 にこの授業において, 著者の一人 (後 閑）が受講学生の立場で設計・製図したへリカル歯車 減速機の組立図を, 図 2 にその部品の一つである入力 歯車軸の図面を示す. ヘリカル歯車減速機の設計・製 眓においては, 図 2 に示した入力歯車軸や中間歯車の 加工法にホブ加工を指定し，それに沿った図面指示を 行っている. また，当該科目では減速機に関する機構 の理解度向上を目的に, 市販の平歯車減速機の分解 ·

平成 23 年 2 月 21 日受付

※ 1 金沢工業大学

※ 2 金沢工業大学大学院
主要寸法測定・組立の実習も取り入れている。しかし ながら，この実習を実施することによって歯車のかみ 合いや固定方法については理解できるものの, 歯車の 加工法であるホブ加工の原理までを理解できる学生は 少ないと考えられる ${ }^{4)}$.

そこで, 著者らは平成 20 年度に扔いて, 工科系学生 に加えて一般人も対象にホブ加工の原理を理解しても らうことを目的に, 展示用教材として「ホブ盤」の設 計・製作プロジェクトを実施した，特に，このホブ盤 では, 学生（高校生を含む）をはじめとして, 多くの 一般人に機械への興味を持ってもらうことも一つの目 的とし, 歯車のみならずボールスプライン軸, ユニバー サルジョイントといった多くのメカニカル要素を取り 入れるように工夫した。

ところで, 指導教員の立場で考えると, 設計・製作 プロジェクトの実施は多くの設計計算書や設計図面, さらには発注部材リスト（価格含む）の確認を必要と するため, 特に研究活動等の多数プロジェクトとの同 時並行指導となる場合, 指導負担は大きい. そこで, 技術文章作成において有効と認められた学生相互添削 方式 ${ }^{5)}$ を設計・製作プロジェクトにも導入し, 学生 同士で図面添削を行うようにしてプロジェクトを実践 した.

本論文では，設計・製作した「ホブ盤」の特徵と効 


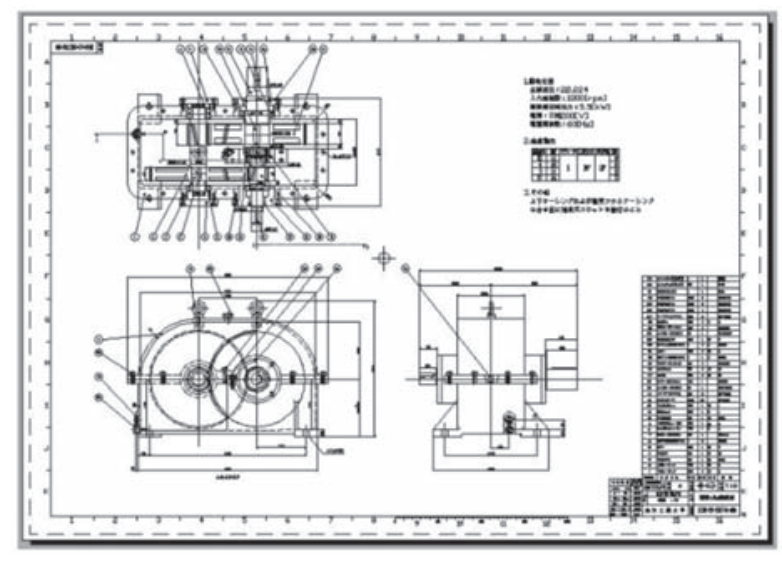

図 1 歯車減速機組立図

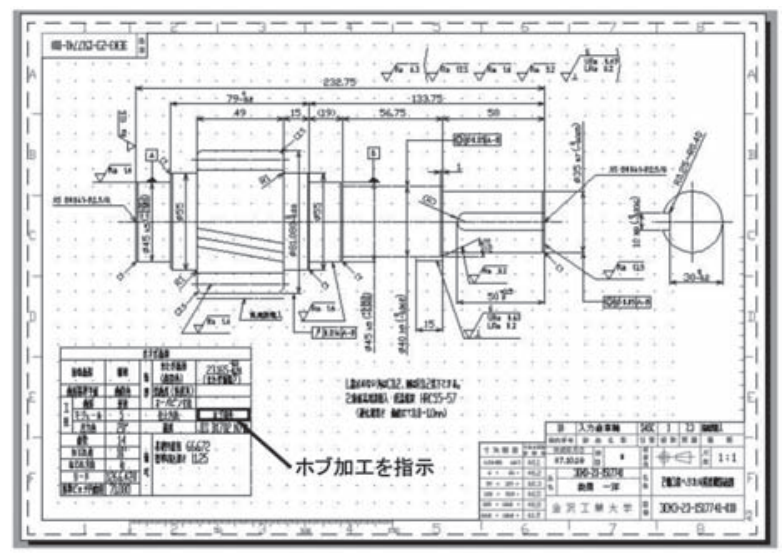

図 2 入力歯車軸部品図

果についてホブ加工の概要と合わせて述べるととも に, 学生相互添削方式を設計・製作プロジェクトに取 り入れた場合に打ける効果についても言及する.

\section{2.一般的なホブ盤とホブ加工の概要}

ホブ盤とは，ホブと呼ばれる回転型専用切削工具を 用いて材料から歯車を削りだす工作機械である。 ホブ の切れ刃はらせん状に設けられており，ホブを用いた 歯切り加工法を一般にホブ加工と呼ぶ. 当該加工の原 理を図 3 に示す. 図 3 に示すようにホブの切れ刃の断 面はラック形状であり，切れ刃のモジュールは創製さ れる歯車のモジュールと等しい，そして，ホブを回転 させることによってラックは回転につれて連続的に移 動する ${ }^{1)}$ 。このとき， ホブの切れ刃が 1 条である場合 には, ホブが 1 回転することで断面のラック形状は 1 ピッチ（1 歯分）移動することになる。したがって， ホブ盤を設計・製作する上では，ホブの回転数と歯車 素材の回転数を同期させる必要がある.

\section{3. ホブ盤の設計条件と特徵}

展示用教材「ホブ盤」は様々な場所（教室や学外展 示会等）で展示を行うことを目的に，「(1) 運搬が容 易であること」を設計条件とした，したがって，展示 用ホブ盤は小型・軽量化を目指した設計を行い，台車

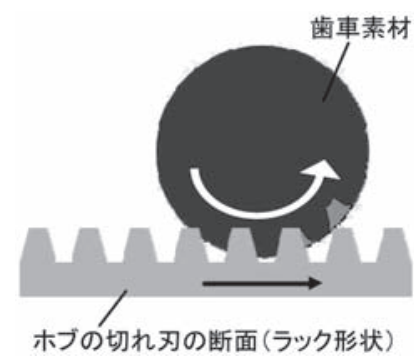

図 3 ホブ加工の原理

表 1 モータの仕様

\begin{tabular}{|c|c|}
\hline 定格動力 & $3.7 \mathrm{~kW}$ \\
\hline 定格回転数 & $1700 \mathrm{rpm}$ \\
\hline
\end{tabular}

表 2 歯車の仕様

\begin{tabular}{|c|c|}
\hline 歯車の種類 & 標準平歯車 \\
\hline モジュール & 5 \\
\hline 歯数 & 20 \\
\hline 歯幅 & $10 \mathrm{~mm}$ \\
\hline
\end{tabular}

表 3 切削条件

\begin{tabular}{|c|c|}
\hline 切り込み量 & $11.25 \mathrm{~mm}$ \\
\hline 歯車素材の回転数 & $4.72 \mathrm{rpm}$ \\
\hline ホブの回転数 & $94.4 \mathrm{rpm}$ \\
\hline 送り速度 & $0.0083 \mathrm{~mm} / \mathrm{rev}$ \\
\hline 切削時間 & $255 \mathrm{~min}$ \\
\hline
\end{tabular}

によって移動可能な寸法とした．また，「(2)ホブ加工 の観察を容易にする」ため切削速度を減速させるこ とに加えて, 「(3) 機械に興味を持ってもらう」ため に, メカニカル要素を多く取り入れることも設計条件 とした。これらの設計条件を踏まえた設計・製作を行 うに当たり, 本プロジェクトでは通常の設計工程とは 異なることになるが, 創製する歯車の仕様よりも先に モータの仕様を表 1 のように決定した。この理由は, モー夕の大きさや動力が, ホブ盤の大きさを決定する 大きな要因となるためである. この仕様を基に切削動 力や強度を計算し, この計算結果から製造できると判 断した歯車の仕様を表 2 に, 切削条件を表 3 のように 決定した。なお，製造する歯車の材質はドライ切削が 可能であり, 大きな切削力を必要としないナイロン MC901とした。 また, 歯車のモジュールは切削の様 子が目視によって確認できるレベルのものとした.

設計・製作したホブ盤を図 4 に，歯車を削りだす前 の材料を図 5 に，当該ホブ盤によって創製した歯車を 図 6 に示す。 また, 歯車の製造（切削）過程中の写真 を図 7 に示す. 図 7 ではホブ加工により, 歯車の溝が 段階的に切削されている様子が確認できる. 以下，本 プロジェクトで設計・製作したホブ盤の特徵を示す。

\section{1 ホブ加工の観察を考慮した切削速度の減速}

本研究では設計計算に基づき, 定格回転数が 


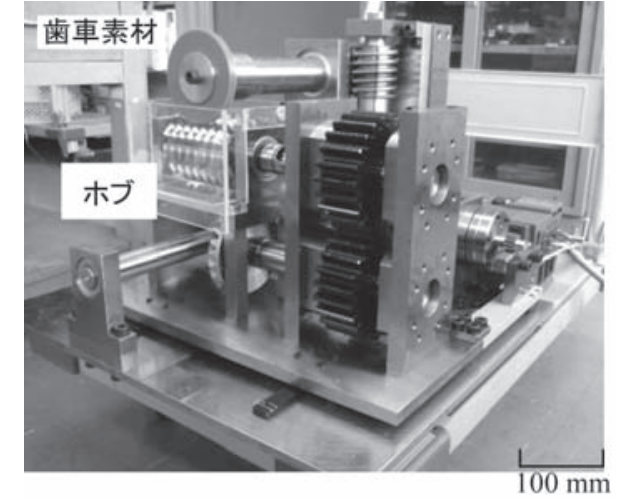

図 4 設計・製作した展示用教材ホブ盤 (安全カバーを外した状態)

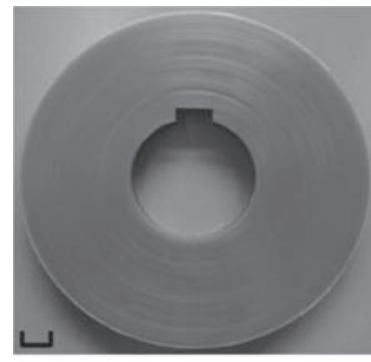

$10 \mathrm{~mm}$

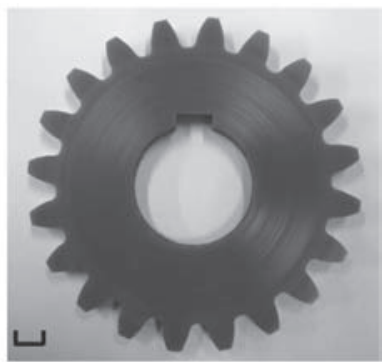

$10 \mathrm{~mm}$

図 6 創製した平歯車
図 5 歯車素材

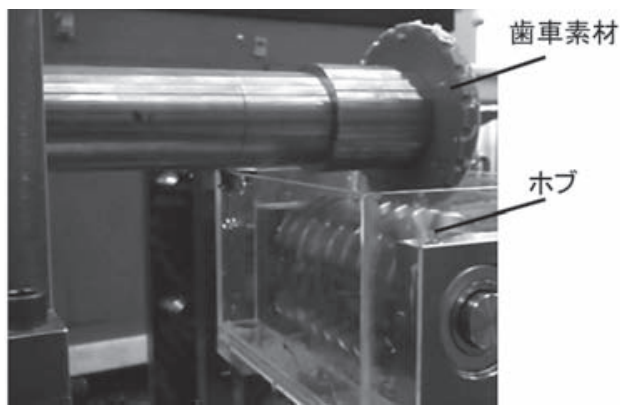

困 7 切削中の様子

1700rpm, 出力が $3.7 \mathrm{~kW}$ の標準三相モー夕（三菱電機 株式会社：SB-JR 112M 4 極）を選定した。しかしな がら，当該モー夕の定格回転数をそのまま使用する場 合，歯車を 1 つ創製するための加工時間は短くなり， 加工機構を目視によって確認することは困難である. そこで，当該モー夕にインバー夕を取り付け，モー夕 の回転数を $1 / 12$ に減速した。これにより，ホブの回転 やホブの送り速度などのすべての運動が減速され，加 工機構の観察が容易となる。 さらには, 送り速度は波 動歯車装置を用いて $1 / 32000 に$ に減速させている，送り 速度を大幅に減速させることによって歯車 1 つを創製 するための加工時間は 4 時間程度となり, 終日に亘る 加工展示を行う場合でも，歯車素材の交換を数回に抑 えることができる

\section{2 回転数の同期方法の機械化}

ホブ加工では, 既述のとおり工具であるホブと歯車 素材をそれぞれ同期回転させて切削を行う必要があ
る ${ }^{1)}$. このためホブ加工では, ホブの回転数と歯車素 材の回転数の同期精度が重要となる. 汎用ホブ盤では, ホブと歯車素材にそれぞれ別々のモータが使用され， 数值制御によって同期を行う CNC 形式が主流となっ ている。しかしながら，この形式ではホブ加工におい て重要となる同期を目視によって確認することが困難 である，そこで，本研究では敢えてモー夕の使用個数 を1つとし，その動力を分岐することによってホブ盤 の主な運動であるホブの回転運動, 歯車素材の回転運 動及びホブの送り運動の 3 つを行う機構とした。これ によりメカニカル要素のみでホブと歯車素材の同期を 行うため, 同期を行っている様子や機構が目視によっ て確認できるようになっている.

\section{3 安全性の考慮}

設計・製作したホブ盤にはホブや多くの歯車が使用 され，それぞれ回転運動を行っている。これらのメカ ニカル要素には, ホブ加工や同期の観察を容易に行う ことができるように，個々のカバーを設置していな い. そこで, 展示の際の安全面を考慮し, ホブ盤全体 を透明アクリル製カバーによって覆い，ホブ盤自体に は触れられないようにしている。これにより，ホブ盤 並びにホブ加工の観察を行う上での安全性を確保して いる.

\section{4. アンケート結果に基づくホブ盤の評価}

設計・製作したホブ盤によって創製される歯車は図 6 で示したように，仕様通りの平歯車となっている. 一方，当該ホブ盤の主目的は，創製した歯車の精度向 上やその使用ではなく, あくまでもホブ加工の原理を 理解してもらうことにある。 そのため当該ホブ盤の評 価は，創製した歯車の精度や生産性で行うものではな く, ホブ加工を観察してもらい, ホブ加工の理解度を もって行うこととした。 また，ホブ加工に使用されて いる多くのメカニカル要素を観察してもらうことを通 して, 機械に興味を持てるかという点も評価項目に加 えた。評価を行うにあたり，2009年 5 月に開催された 機械工業見本市金沢（主催：社団法人石川県鉄工機電 協会）において大学生を中心に高校生や一般人（その 多くが工業系企業に従事) を対象に, 当該ホブ盤とそ れによる加工状況を説明した上でアンケート調査を 行った（図 8). アンケートの内容とアンケート結果 を図 9 に示す。ここで，アンケートの回答人数は 67 人 であった.

図 9 の結果から, 歯車の製造方法であるホブ加工を 知っていた人は半分程度であることがわかる。この数 值は意外に大きいと思われるが，アンケート調查を 行った場所が機械工業見本市金沢であり，その参加者 の殆どが機械系学生や工業系企業に従事する人達で あったためと考えられる。また, 実際にホブ加工を観 察してもらうことを通じて, 多くの見学者にホブ加工 
を理解してもらうことができた，さらに，当該ホブ盤 に使用されているメカニカル要素を見てもらうことに よって, 機械の機構に興味を持つ学生が増えたという

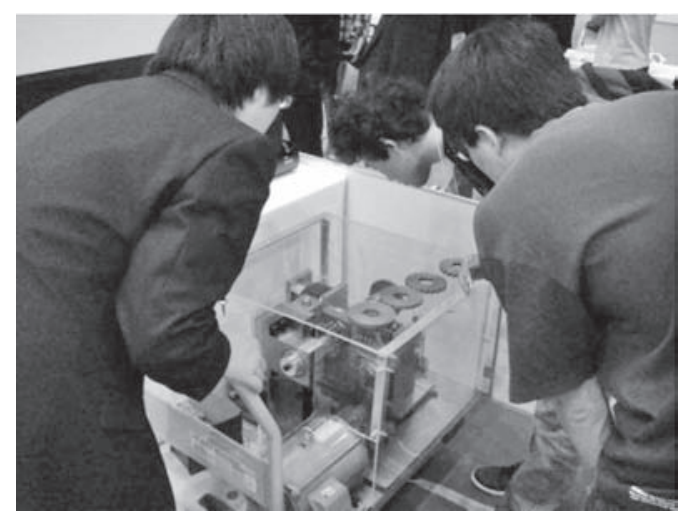

図 8 機械工業見本市金沢

1. 歯車はどのように作られるか知っていますか.

2、ホブ盤というものを知っていますか.

3. ホブ加工を実際に見たことがありますか.

4. 今回, ホブ盤で歯車ができる様子を見学して歯車がどの ように作られるかわかりましたか.

5. 機械の機構を面白いと思いますか.

6. 機械について興味を持ちましたか.

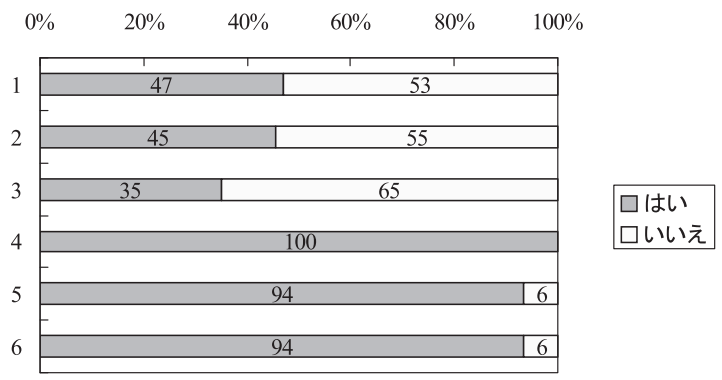

(a) 全体の結果（回答数：67）

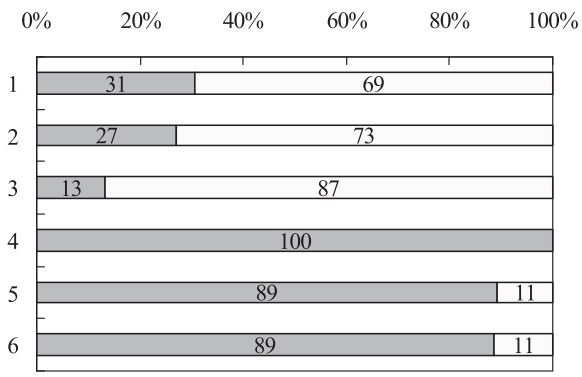

（b）学生（高校生を含む）の結果（回答数：40)

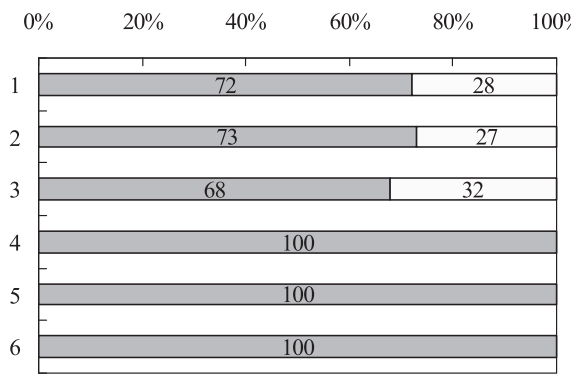

(c) 一般人の結果（回答数: 27）

図 9 アンケート結果
結果を得た.

以上の結果より, 設計・製作したホブ盤は目的を達 成し，展示用教材としての性能を有していると考えら れ，現在は既述の必修科目「機械設計演習」における 教材として使用している. 今後も授業や多くの展示会 においてホブ加工を実演することを通して，学生並び に一般人のホブ加工に対する知識を深められるよう努 力する所存である.

\section{5. 設計・製作プロジェクトへの相互添削方式の 導入効果}

\section{1 本研究室の指導体制と平成20年度の概要}

本研究室では精密工学及び振動応用工学を主たる専 門分野とし，設計・製作プロジェクトのみならず，多 くの研究指導を実践している。具体的には，(1)大学 でこそ可能となる基礎・応用・展開型研究の推進をは じめ, (2) 産官等との連携による共同研究や公的機関 からの助成研究を実践するとともに，(3) ものづくり 教育，のプロジェクトを実践している。 そして, 平成 20年度においては10のプロジェクトのうち, (1) 2 テー マ（修士 2 名, 学部 1 名), (2) 5 テーマ（修士 1 名, 学部 5 名), (3) 3 テーマ(学部 3 名) という内訳で実 践してきた.

そして，平成20年度においては既述した「ホブ盤」 とともに,「3 軸 2 段へリカル歯車減速機」, 並びに 「マイクロホンアレーシステム」の設計・製作に学部 各 1 名で取り組んだ。図10にそれぞれの完成写真を示 す.

\section{2 学生相互添削の有効性の評価}

少人数の指導体制で比較的多数のプロジェクトを実 施する場合, 設計・製作プロジェクトの細部までを確 認することは難しい，そこで本研究室では，平成18年 度から技術文章作成における学生相互添削方式 ${ }^{5)}$ 導入しているが，それを設計・製作プロジェクトにお ける, 特に設計解（設計計算書, 設計図面, 価格を含 む発注部材リスト）の相互添削にも適用した。表 4 は 平成20年度に実施した $3 つ の$ 設計・製作プロジェクト を完成させるまでの年間活動フローであり, 図 11 は相 互に設計解を確認・添削し合う学生の様子である。こ
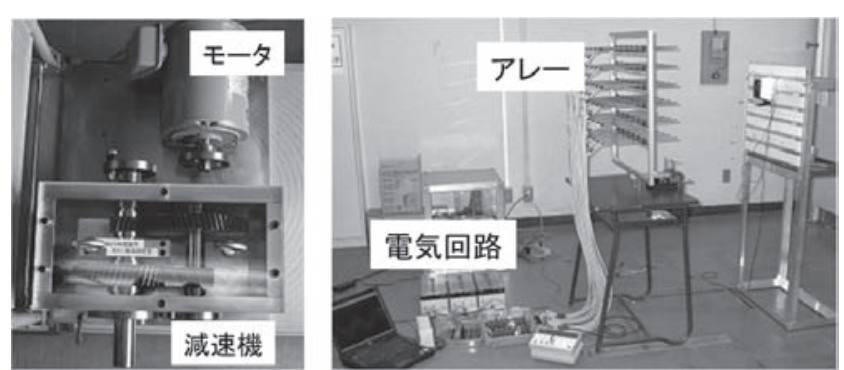

図10 設計・製作したヘリカル歯車減速機とマイクロホン アレーの外観 
表 4 年間活動フロー

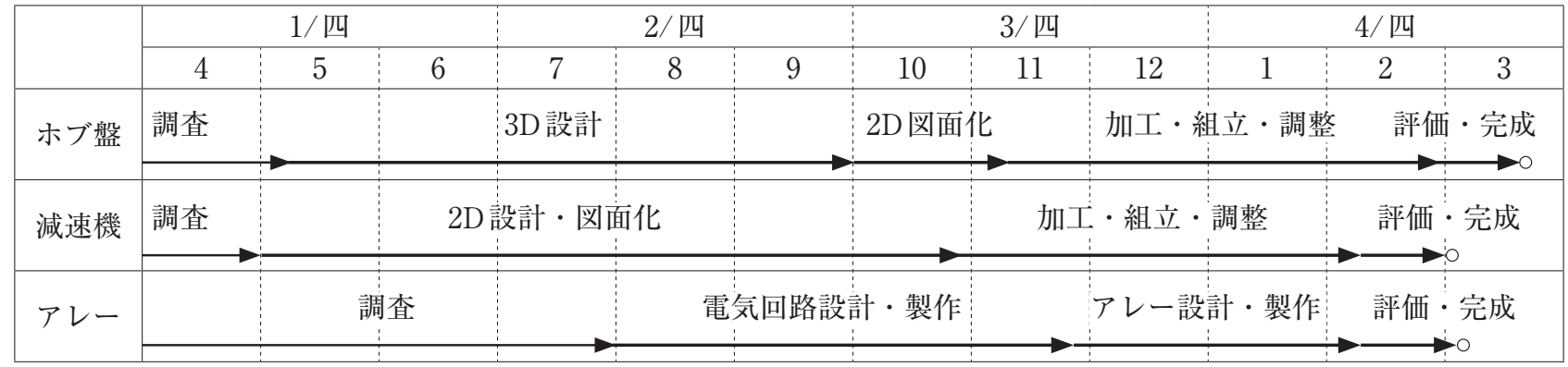

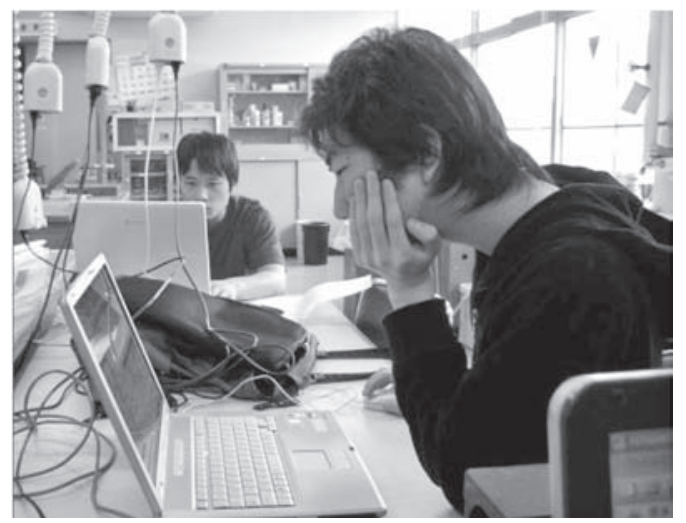

図11 相互添削する学生

のように，いずれも設計に非常に多くの時間を要して いるが，特にメカニカル要素を多く含む「ホブ盤」, 並びに「 3 軸 2 段へリカル減速機」のプロジェクト遂 行には進行度合いをできる限り揃えるようにして指 導・実践した，その結果，いずれのプロジェクトでも 活動目標について計画通りの成果を修めることができ ている。 これらのことから，学生相互添削方式は技術 文章作成のみならず，設計・製作プロジェクトを円滑 に進めるためにも有効な方策であると言える.

\section{6. 結言}

本論文で得た結果を要約すると, 以下のようになる.

1 ）安全性を考慮しつつ, メカニカル要素を多く取り 入れ，ホブ加工並びに同期の原理を理解しやすい展 示用教材であるホブ盤を設計・製作した。

2）アンケート調査から，当該ホブ盤は教材に資する という結果を得た。
3 ) 学生相互添削方式は, 設計・製作プロジェクトの 指導に適用しても有効である.

\section{参 考 文 献}

1 ) 歯車工作技術研究会：よくわかる歯車と歯切り作 業法, 理工学社, 3.10-3.13, 1977

2 ) 畧田道雄, 藤木信彰：機械系設計・製図科目にお ける授業改善活動とその効果検証, KIT-Progress (工学教育研究), 12, 69-77, 2007

3 ) 畧田道雄, 藤木信彰, 津軽武彦, 堀 利正 : 機械設 計演習(ヘリカル減速機編), パワー社, 2009

4) 山田高三, 李 和樹: 工業教育用ホブ盤の開発と その実習, 工学・工業教育研究講演会講演論文集, $714-715,2007$

5 ) 畧田道雄, 石川憲一：論文作成指導の高効率化を 目的とした技術文章作成能力向上のための試みと 有効性評価, 工学教育, $58-2$, pp.58-63, 2010

\section{著者紹介}

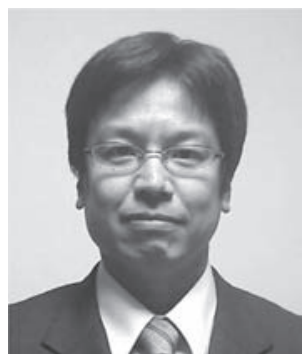

\section{畧田 道雄}

2000年金沢工業大学大学院工学研究科博 士後期課程機械工学専攻修了, 博士（工 学). 2000年防衛庁技術研究本部, 防衛庁 技官. 2002年金沢工業大学助手. 現在, 同准教授. 九州大学客員准教授 (兼務). 専門は精密工学 (精密加工, 精密計測), 振動応用工学. 所属学会は日本機械学会, 精密工学会, 砥粒加工学会, 日本設計工 学会など. 上級教育士 (工学・技術). 